\author{
KÜLLIYE \\ ULUSLARARASI SOSYAL BILIMLER DERGISII \\ INTERNATIONAL JOURNAL OF SOCIAL SCIENCES
}

\title{
Muhafazakârlığa Yönelik İki Yaklaşım: Ana Temalar Ekseninde Siyasî ve Durumsal Muhafazakârlık
}

\author{
Fatma Zehra LALEOĞLU*
}

$\ddot{O} \mathbf{z}$

Muhafazakârlık tanımları iki temel yaklaşım üzerinden yapılmaktadır. Bu yaklaşımların ilki "siyasî muhafazakârlık", ikincisi ise "durumsal muhafazakârlık" olarak adlandırılmaktadır. Bu makalede öncelikle mezkur iki yaklaşım üzerinden "muhafazakarlık" tartışması gerçekleştirilmektedir. İkinci olarak ise gelenek, değișim, din, aile ve toplum, devlet ve otorite, mülkiyet, ahlaki düzen temaları değerlendirilmiștir. Bu temalar üzerinden siyasî ve durumsal muhafazakârlığın ortak ve farklı yönleri ele incelenmiş; siyasî ve durumsal muhafazakârlığın bu temalara yaklaşımının büyük ölçüde örtüştüğü görülmüştür. Bununla birlikte iki yaklaşım arasında bazı nüanslar da mevcuttur. Örneğin siyasî muhafazakârlıkta gelenek daha ziyade dini kurumlar, kulüpler, üniversiteler, vakıflar ve diğer benzeri kurumları temsil eden somut bir gerçeklik olarak addedilmektedir. Durumsal muhafazakârlığa bakıldığında gelenek, tutum ve davranışları șekillendiren norm ve değerler olarak ön plana çıkmaktadır. Değişim özelinde ele alındığında ise durumsal muhafazakârlık diğer ideolojilere eklemlenebilmekte ve bu ideolojilerin koruyucusu olabilmektedir. $\mathrm{Bu}$ haliyle siyasî muhafazakârlıktan farklı olarak ideolojiler üstü bir konuma erişmektedir. Öte yandan otorite bağlamında değerlendirildiğinde siyasi muhafazakârlığın kimi zaman otoriter kimi zaman da paternalist olarak değerlendirildiği görülmektedir. Bu tür değerlendirmelerin en önemli sebebi muhafazakârlığın otorite vurgusudur. Genel olarak bakıldığında ise durumsal muhafazakârlığın daha bireysel bir tavır alışı; siyasî muhafazakârlığın ise daha kurumsallaşmış bir düşünce sistemini ifade ettiğini söylememiz mümkündür. Otorite.

Anahtar Kelimeler: Siyasî Muhafazakârlık, Durumsal Muhafazakârlık, Gelenek, Değişim, Din,

\section{Two Approaches to Conservatism: Political and Situational Conservatism in the Axis of Main Themes}

\section{Abstract}

Definitions of conservatism are made on two basic approaches. The first of these approaches is called "political conservatism" and the second is called "situational conservatism". In this article, first of all, the discussion of "conservatism" is made over these two approaches. Secondly, the themes of tradition, change, religion, family and society, state and authority, property, and moral order are evaluated. The common and different aspects of political and situational conservatism have been examined through these themes. The approach of political and situational conservatism to these themes mostly similar. However, there are some differences between the approaches. For instance, in political conservatism, tradition is instead viewed as a concrete reality representing institutions. On the other hand, situational conservatism considers tradition as norms and values that shape attitudes. When it was considered in the context of change, situational conservatism can be articulated to other ideologies and protect them. Besides, when approaches are compared in the context of authority, it is seen that political conservatism is sometimes evaluated as authoritarian or paternalist. As a result, situational conservatism has a more individual attitude. However, political conservatism represents a more institutionalized system of thought.

Keywords: Political Conservatism, Situational Conservatism, Tradition, Change, Religion, Authority.

* Yüksek Lisans Öğrencisi, Ankara Yıldırım Beyazıt Üniversitesi, Sosyal Bilimler Enstitüsü, Felsefe Ana Bilim Dalı, Ankara / Türkiye, e-mail: laleogluzehra@gmail.com.

ORCID (D: https://orcid.org/0000-0003-3777-5494.

Bu makaleyi şu şekilde kaynak gösterebilirsiniz / To cite this article (APA):

Laleoğlu, Fatma Zehra (2021). "Muhafazakârlı̆ga Yönelik İki Yaklaşım: Ana Temalar Ekseninde Siyasî ve Durumsal Muhafazakârlık". Külliye, 2 (1): 1-17. DOI: 10.48139/aybukulliye.858322.

Makale Bilgisi / Article Information

\begin{tabular}{|c|c|c|c|}
\hline Geliş / Received & Kabul / Accepted & Türü / Type & Sayfa / Page \\
\hline 12 Ocak 2021 & 17 Şubat 2021 & Araştırma Makalesi & \multirow{2}{*}{$\mathbf{1 - 1 7}$} \\
\hline 12 January 2021 & 17 February 2021 & Research Article & \\
\hline
\end{tabular}




\section{Extended Abstract}

Definition of conservatism is the subject of a long-standing debate. This issue has remained on the agenda for so long because of difficulties and diversity of the concept. There are two basic approaches to conservatism, and these approaches also shape the definitions. The first one accepts conservatism as an ideology that emerged immediately after the French Revolution. According to this approach, conservatism emerged as an opposition to the modern principles brought by the Revolution. It has been defined as the third primary ideology besides liberalism and socialism. Edmund Burke's Reflections on the Revolution in France (1790), in which he seriously criticized the Revolution, has been accepted as the main text of political conservatism. The second approach, called situational conservatism, defines conservatism as a general and behavioural attitude towards life. The most defining point of this attitude is the distance to modernity and changes, and preference of the existing against the new. In this form, conservatism expresses a general attitude that exists in different ways in every society.

However, both approaches have their dilemmas. Conservatism, as an ideology, unlike others, does not offer a utopia to people. Besides, it does not have strict lines like other ideologies such as liberalism, socialism and fascism, and every country and society could have their different variant of conservatism. Therefore, it creates some complexity to conservatism as an ideology. On the other hand, when conservatism accepted as an attitude, it is possible to create confusion about actions and behaviours. In this context, firstly, the definition of conservatism and its two approaches are examined by using the literature review method. In the second part of the article, themes such as tradition, religion, state, authority, family, society and morality accepted and discussed as the main themes of conservatism. Political and situational conservatism is common and differentiated regarding how these main themes evaluated to contribute to the literature.

Tradition, which is the first of the main themes, is accepted as the essential reference for both approaches. Tradition, first of all, expresses the identity of society. Hence, tradition has vital importance for both political and situational conservatism. However, in political conservatism, tradition is mostly related to religious institutions, foundations etc. and considered concrete reality for representations. On the other hand, in situational conservatism, tradition stands out as norms and values that shape attitudes, actions and behaviours.

As another issue, the caution towards change is the main character of conservatism. However, especially situational conservatism defined by the attitude against change. Thus, considering that every ideology has definite principles and tried to be protected themselves to other ideologies. It can also be the protector of the current doctrines of articulated ideologies. So, unlike political conservatism, it reaches a position above ideologies. 
In conservatism, the concepts of state, authority and hierarchy are dealt with concerning each other. In conservative thought, the authority has a vital role in determining the relations between individuals, institutions and the state. Both in political and situational conservatism, social classes are seen as the natural outcome of understanding authority. Conservatism defends that social classes and hierarchal structure are the outcomes of society's nature, because of this reason, social equality accepted as an unachievable ideal. This approach has led to the evaluation of political conservatism as "aristocrat ideology". On the other hand, the emphasis on authority has caused political conservatism, sometimes, authoritarian or paternalist.

In both conservatism approaches, property rights are considered freedom and protection of the private property as guaranteeing freedoms. However, political conservatism put right to property against expropriation. As other main themes, family, society and morality are equally crucial in political and situational conservatism. For both approaches, the family accepted as a vital base of society. Also, society is evaluated as an organic entity, not as a made up of individuals, and the individual exists in society. Finally, both in political and situational conservatism, god, the universe, nature and politics are all built on moral order and created a necessity of a moral positioning.

\section{Giriş}

Muhafazakârlığın ne olduğu sorusu, uzun zamandır süregelen bir tartışmanın konusudur. Konunun bu kadar uzun süre gündemde kalmasının, kavramın tanım güçlügüunden ve çeşitliliğinden kaynaklandığı düşünülmektedir. Bu çeşitliliğe rağmen muhafazakârlık söz konusu olduğunda iki temel yaklaşımın ön plana çıktığ1 görülmektedir. İlk yaklaşımda muhafazakârlık, siyasî bir ideoloji olarak değerlendirilmektedir. Bu yaklaşıma göre muhafazakârlık, 1789'da yaşanan Fransız Devrimi'ne ve devrimin getirdiği modern ilkelere karşı çıkan bir ideoloji olarak teşekkül etmiştir. Edmund Burke'ün devrimi ciddi bir şekilde eleştirdiği Fransız Devrimi Üzerine Düşünceler (1790) isimli eseri de siyasî muhafazakârlığın ana metni olarak kabul görmüştür.

İkinci yaklaşımda muhafazakârlık, bir tutum olarak değerlendirilmektedir. Bu tutumun en belirleyici özelliği yeniliklere ve değişimlere karşı mesafeli olunması; mevcut olanın yeni olana tercih edilmesidir. $\mathrm{Bu}$ anlamıyla muhafazakârlık her toplumda var olan ve ne zaman ortaya çıktığı tam olarak belirlenemeyen bir tutumdur. Muhafazakârlık tanımları genel olarak bu iki yaklaşım üzerinden yapılmaktadır. Açıkçası muhafazakârlığın bir ideoloji mi yoksa bir tutum mu olduğu meselesi de hala üzerinde uzlaşılmış bir konu değildir. Bu bağlamda konuyla ilgili mevcut literatüre katkıda bulunma amacıyla kaleme alınan bu çalışmada ilk olarak muhafazakârlık tanımlamalarındaki güçlükler incelenmiş; mevcut tanımların öne çıkanları aktarılmıştır. Daha sonra muhafazakârığgn ana temaları olarak kabul edilen gelenek, din, devlet, hiyerarşi ve otorite, aile ve toplum,

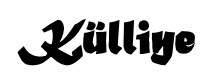


ahlaki düzen gibi unsurlar ele alınmış; siyasî ve durumsal muhafazakârlığın bu unsurlara yaklaşımındaki ortaklık ve farklılıklar ortaya konulmaya çalışılmıştır.

\section{Muhafazakârlık Nedir?}

Muhafazakârlık kavramı yazılı olarak ilk kez 1820'de Chateaubriand'ın Fransa'da yayınlanan Le Conservateur adlı dergisinde kullanılmıştır. Fakat muhafazakârlığın felsefi bir kavram olarak arka planı Edmund Burke'ün Fransız Devrimi Üzerine Düşünceler isimli çalışmasını kaleme aldığı 1790 yılına kadar dayandırılmaktadır (Akıncı 2009: 137). Burke'ün bu eseri muhafazakâr düşüncenin ana metni olarak kabul edilmektedir. Bu eserinde Burke, "muhafazakârlık" kavramını kullanmış olmasa da sık sık "muhafaza etmek" ifadesini kullanmıştır (Yılmaz Ceylan 2007: 27). Burke, her ne kadar muhafazakâr düşüncenin kurucusu olarak kabul edilse de bir davranış biçimi olarak muhafazakârlığın daha öncesinde var olduğunu söylemek mümkündür. Bu tutumun köklerini klasik düşünceye kadar geri götüren Morton Auerbach, muhafazakârların arasına Cicero, Saint Augustin, Thomas More gibi isimleri de dâhil etmektedir (Beneton 1991: 6).

Muhafazakârlığı tanımlamanın güç bir iş olduğu belirtilmektedir. R.J. White, bu güçlüğün muhafazakârlığın tabiatından kaynaklandığını ifade etmiştir. Çünkü ona göre muhafazakârlık, politik bir doktrinden ziyade bir zihin alışkanlığı ve yaşam tarzıdır (Harries 2003: 29). Bununla birlikte muhafazakârların da muhafazakârlık tanımı üzerinde çok durmadığı, sıklıkla dile getirilen bir eleştiridir. $\mathrm{Bu}$ bağlamda Owen Harries, Avustralya'nın önde gelen muhafazakâr dergisi Quadrant'1 örnek göstererek bu dergide "muhafazakârlık nedir?" sorusuna yönelik kaleme alınmış herhangi bir makale olmadığını ifade etmektedir (2003: 29). Bu durum muhafazakârlık tanımlarının çeşitlenmesi ve farklılaşmasıyla sonuçlanmıştır. Örneğin Samuel Huntington muhafazakârlık tanımlarını üçe ayırmıştır. Bunların ilkine göre muhafazakârlık, feodal ve aristokrat yapıların Fransız Devrimi'ne tepkisini içeren bir ideolojidir. İkinci tanıma göre muhafazakârlık; düzen, denge, ölçülülük gibi değerlere dayanan otonom bir sistemdir. Üçüncü tanımda ise muhafazakârlık, farklılaşma ve değişim karşıtlığından kaynaklanan bir unsur olarak ele alınmaktadır (Huntington 1957: 454-455). Bu tanımların birincisi "aristokratik tanımlama" olarak adlandırılmaktadır. Huntington'a göre bu tanım, muhafazakârlığı belirli bir toplumdaki belirli bir sosyal sınıfa özgüleyerek sınırlamaktadır. "Otonom sistem" tanımı, muhafazakârlığın herhangi bir tarihsel aşamada ortaya çıkabileceğini ifade etmektedir. Son tanım ise durumsal muhafazakârlı̆̆ı nitelemektedir (Huntington 1957: 454-465).

Michael Oakeshott ise muhafazakârlı̆̆ belli biçimlerde düşünme ve davranma eğiliminde olmak, belirli davranışları diğerlerine tercih etmek, belirli seçimleri yapmaya meyyal olmak şeklinde tanımlamaktadır (1991: 168). Tanımda yer alan "belirli tür davranışlar" oldukça muğlak görünmekte ve bu tür davranışların nasıl tespit edileceği başlı başına bir sorunu ortaya çıkarmaktadır. Ancak Oakeshott, söz konusu davranışların niteliklerinin belirlenmesinin zor olmadığını ifade

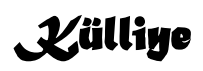


etmektedir. Ona göre muhafazakârlık, sınırlıyı sınırlanmamış olana; aşina olunanı bilinmeyene, mevcut olanı muhtemel olana, yakını uzağa tercih etmektir (1991: 169). 20. yüzyılın önde gelen muhafazakâr düşünürlerinden biri olan Russell Kirk de muhafazakârlığın birtakım prensipleri olduğunu ve bu prensipler üzerinden tanımlanabileceğini söylemiştir. Söz konusu prensiplere göre muhafazakârlar aşkın bir düzene ve doğal hukukun varlığına inanan, geleneğe ve dine bağlı olan, değişime temkinli yaklaşan ve toplumsal sınıfların varlığını savunan insanlardır (Kirk 2005: 141-142).

\subsection{Siyasî Muhafazakârlık}

Siyasî ideoloji olarak ele alınan muhafazakârlık, sosyalizm ve liberalizm ile birlikte modern çağın üç büyük ideolojisi arasında yer almaktadır. Bununla birlikte siyasî muhafazakârlık genellikle "sağ ideoloji” olarak adlandırılmaktadır.

Robert Nisbet, Karl Mannheim, John Kekes gibi isimler, belirli bir sosyal duruma ve tarihe bağlı olmasını gerekçe göstererek muhafazakârlığı bir ideoloji olarak ele almıştır. Liberalizmi burjuva ideolojisine, sosyalizmi proleter ideolojisine bağlayan Mannheim, muhafazakârlığı aristokrat ideolojiye bağlamıştır (Huntington 1957: 454). Philippe Beneton ise muhafazakârlı̆̆ın statükoya ve değişim korkusuna bağlı kalarak açıklanamayacağını belirtmektedir. Nitekim ona göre bu haliyle muhafazakârlık bütün zamanlara ait bir şey olup çok çeşitli bir hal alacaktır. Bu anlamda söz konusu mefhum, muhafaza edilmesi gereken şeylerin niteliği kökten farklı olsa bile Roma'dan Sovyet Rusya'ya kadar pek çok medeniyeti ve toplumu kapsayacaktır. Böylece Beneton'a göre kavram, siyasî fikirler tarihi açısından tahlile elverişli olmaktan çıkacaktır. Bu gerekçelerle Beneton, muhafazakârlığın modern zamanlarda doğan ve modernliğe karşı çıkan bir siyasî hareket olarak tanımlanması gerektiğini belirtmektedir (Beneton 1991: 10-11).

Nisbet, Mannheim, Kekes gibi isimlerin aksine bazı düşünürler muhafazakârlığın bir ideoloji olmadığını savunmaktadır. İdeolojinin tanımı konusunda her ne kadar fikir birliği olmasa da ideolojinin özellikleri arasında insanlara sunulan bir ütopyanın varlığı, üzerinde anlaşılmış bir konu olmuştur. Bilindiği gibi ütopya, var olan düzenden memnun olmayanların yeni bir yapı tasavvur etmesi, ideoloji ise bu yapı düzeninin aşkınlaştırılma biçimidir (Mannheim 2004). Muhafazakârlığı bir ideoloji olarak değerlendirmeyenler, bunun gerekçesi olarak genellikle onun ulaşmak için uğruna mücadele edilen bir ütopyasının olmamasını öne sürmektedir. Ancak muhafazakârlık bir düşünce üslubu olarak diğer ideolojilere eklemlenebilmekte veya mevcut siyasî bir doktrinin koruyucusu haline gelebilmektedir. Böylece muhafazakârlık bir karşı ideoloji olarak da değerlendirilebilmektedir (Vural 2011: 47). Huntington da muhafazakârlıkta ideal bir toplum anlayışının ve tek bir muhafazakâr ütopyanın bulunmayışına dikkat çekmiştir (1957: 458). Bunun en önemli nedeni her toplumun muhafaza etmeyi hedeflediği düzenin farkl1lık göstermesidir. Bununla birlikte Huntington'a göre muhafazakârlık içerik ile ilgili değil; usul, değişism ve istikrarla ilgilidir. Dolayısıyla

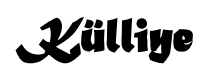


liberalizmden sosyalizme kadar her türlü düzenin devamı ve savunması için kullanılabilmektedir (Harries 2003: 35).

Diğer taraftan muhafazakârların pek çoğu, muhafazakârlığı "ideolojiler üstü" olarak değerlendirmektedir (Mollaer 2009: 35-36). Bu muhafazakârlar ideolojileri eksik kavrayışa sahip bir anlatım olarak değerlendirmektedir. Örneğin Cemil Meriç, ideolojileri insanların idraklerine giydirilmiş "deli gömlekleri” olarak nitelendirmiştir (Meriç 2015: 92). Meriç örneğinde de olduğu gibi muhafazakâr düşünürlerin ideolojik bir konumlanmadan kaçındığını söylememiz mümkündür. Ayrıca muhafazakâr düşünceye göre her ideoloji değişimi zorlamakta ve düzeni, ahengi bozmaktadır (Vural 2011: 47). Buna karşın muhafazakârlık değişimin kendisine mesafeli yaklaşmaktadır.

\subsection{Durumsal Muhafazakârlık}

Durumsal muhafazakârlık, daha ziyade meydana gelen köklü değişimlere karşı oluşan direnme eğilimini ifade etmektedir. Bu eğilim, kişinin gündelik davranışlarına yansımakta ve bir psikolojik tutumu ve tavır alışı nitelemektedir. Durumsal muhafazakârlığın en önemli özelliği geleneklere bağlılık, durağanlık, ait olduğu sınıfin diğer üyelerine benzemek için aşırı çaba ya da onlardan ayrı düşme endişesi, istikrar arayışı, olağandışı ve düzensiz olana karşı duyulan ölçülülüktür (Vural 2011: 42).

Muhafazakarlığı bir tavır ve tutum olarak değerlendiren Michael Oakeshott, muhafazakârlığı politik konteksinden ayrı olarak ele almış ve gündelik hayattaki pek çok davranışın, örneğin balık tutmanın, muhafazakâr bir eğilime sahip olduğunu söylemiştir. Zira o, temel amacın başarmak değil sadece yapılan işten zevk almak olduğu tüm faaliyetlerin muhafazakâr olma eğilimi taşıdığını belirtmiştir (Oakeshott 1991: 177-178). Oakeshott'un sözünü ettiği bu muhafazakârlık, "ontolojik muhafazakârlık" olarak da adlandırılmaktadır. Oakeshott'un yanı sira Roger Scruton, Russel Kirk, Owen Harries gibi isimler de muhafazakârlığı bir ideoloji olarak değil, bir tutum olarak ele almaktadır. Scruton, muhafazakârlığın kendini genel ilkeler ve formüller biçiminde ortaya koymadığını, bu sebeple de esasının anlaşılamadığını savunmaktadır (Vural 2011: 44-45).

Muhafazakârlığı bir tutum olarak değerlendiren düşünürler onun her zaman ve her toplumda var olduğuna dikkat çekmektedirler. Ancak burada dikkat edilmesi gereken nokta, muhafazakârlığın her toplumda farklı şekillerde var olmasıdır. Nitekim korunması hedeflenen her durum ve değer toplumdan topluma farklılık göstermektedir. Tüm toplumlarda homojenlik göstermemesi, muhafazakarlığı diğer ideolojilerden ayıran ve "tutum" olarak ele alınmasını sağlayan en önemli etkendir.

\section{Ana Temalar}

\subsection{Gelenek}

Geleneği bir toplumda saygı duyulan ve kuşaktan kuşağa aktarılan kültürel kalıntılar, alışkanlıklar ve bilgiler bütünü olarak tanımlamak mümkündür. Geleneğin en önemli işlevi, toplum içinde birtakım davranış kalıplarını üretmesi ve toplumun bu kalıplara göre davranmasına yönelik yaptırım gücünün olmasıdır.

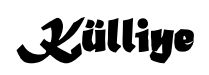


Gelenekler muhafazakârlığın en temel referansıdır. Muhafazakârlar, yaşamlarını geleneklerine göre şekillendirmektedir. Ancak burada geleneğe sadece körü körüne bağlılık söz konusu değildir. Zira gelenek bir bilgi kaynağını, toplumsal tecrübelerin toplamını ve herhangi bir ideolojiden veya teoriden çok daha önemli bir yol göstericiyi ve sorun çözücüyü ifade etmektedir. Toplumsal tecrübelerin sonucu olan geleneksel bilgiler, insanın tek başına erişebileceği türden bilgiler değildir. Bu anlamda insan aklından çok daha derindir. Muhafazakârlara göre gelenekler, "zamanının imtihanlarını" geçmiştir. Bu sebeple de yaşayanların ve gelecek kuşakların menfaati için korunmalıdırlar (Şeyhanlığlu 2014: 86). Geleneğin korunması demek aynı zamanda onun sürekliliğinin sağlanmasıdır. Bu korumanın en önemli yollarından biri yasaların geleneklere dayandırılmasıdır.

Muhafazakâr düşüncede geleneğin sürekliliği toplumun kimliğinin omurgasını oluşturmaktadır. Gelenek, bireye aidiyet hissi vermekte, bireyin kendi kimliğinin bilincine varmasını sağlamakta ve onu köksüzlük duygusunun boşluğuna düşmekten korumaktadır (Erdoğan 2004: 5). Tecrübeyle kanıtlanmış yerleşik pratikleriyle kişileri her türlü değişikliğin ve yeniliğin yol açtığ belirsizlikten kurtarmaktadır. $\mathrm{Bu}$ pratikler insanların üzerine düşünüp inşa edebileceği türden pratikler değildir. Nesilden nesile tevarüs etmesi ve günümüze ulaşması pratiklerin en önemli özelliğidir.

Geleneğin muhafazakâr düşüncedeki önemi, zaman zaman muhafazakârlık ve gelenekçiliğin karıştırılmasına neden olmuştur. Mannheim, muhafazakârlığın bilinçli gelenekçilik olduğunu söyleyerek ikisi arasındaki farkı vurgulamıştır. Beneton ise muhafazakârlığın bir tür gelenekçilik olduğunu fakat gelenekçiliğin mutlaka muhafazakârlık olmadığını belirtmiştir (1991: 113). Bu açıklama, muhafazakârlık ve gelenekçilik arasındaki ayrımı anlamak için önemlidir.

Hem durumsal hem de siyasî muhafazakârlıkta geleneğe atfedilen anlam ve önem birbiriyle büyük ölçüde örtüşmektedir. Ancak daha derinlemesine bakıldığında ikisi arasında bazı nüanslar bulmak mümkündür. Örneğin siyasî muhafazakârlık için gelenek soyut bir şey değil aynı zamanda kurumlarla birlikte somutluk kazanan ve sosyal kurumları ifade eden bir gerçeklik alanıdır (Erdoğan 2004: 6). Toplum ve bireyler, bu kurumlar aracılığıyla devlet karşısında belirli bir ölçüde bağımsızlık elde etmektedir. Bununla birlikte siyasî muhafazakârlık için geleneğin, kurumların yanı sıra yönetim biçimiyle de somutlaştığını söylememiz mümkündür. Bilginin kaynağı kabul edilen gelenek, ideal yönetim biçimine dair bilgiyi de kendinde barındırmaktadır. Örneğin Maistre ve Burke, Ortaçağ'da neredeyse tüm Avrupa'ya egemen olan; monarşi, aristokrasi ve dinin sacayağını oluşturduğu yönetim şeklinin sürdürülmesi gerektiğini savunmuştur. Durumsal muhafazakârlıkta ise gelenekler özellikle norm ve değerler bağlamında değerlendirilmektedir. Son olarak durumsal muhafazakârlıkta geleneğin "toplumsal sürekliliği" ifade ettiğini, siyasî muhafazakârlıkta ise daha çok "siyasî istikrar"ın temeli olarak görüldügüunü ifade edebiliriz. Elbette siyaset ve toplumun birbirinden

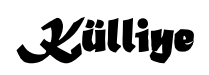


ayr1lamayan iki unsur olduğu düşünüldüğünde, toplumsal süreklilik ve siyasî istikrarın da birbiriyle sıkı bir ilişki içinde olduğu görülecektir.

\subsection{Din}

Muhafazakârlık çoğu zaman dindarlıkla özdeş olarak kullanılmaktadır. Fakat dindarlar için muhafaza edilmesi gereken din ve dine ilişkin değerler iken muhafazakârlık öncelikle üsluba ilişkin bir vurgudur (Mert 2002: 72). Bu anlamda dindarlık bir çeşit muhafazakârlık sayılabilir. Fakat muhafazakârlık dindarlıktan çok daha geniş bir anlam ufkuna sahiptir. Onu dine ve dindarlığa indirgemek yanıltıcı olacaktır. Muhafazakârlık, değişimin toplumsal ortam ve yapı üzerinde yaratacağı yıkıma karşı mevcut olanın korunmasıdır. Fakat bu tavır değişime karşı köklü bir ret değildir. Toplumsal hiyerarşiler, kurumlar, kültürel değerler korunduğu sürece, bu unsurlar çerçevesinde değişim mümkündür (Mert 2002: 72). Dinde ise böyle bir değişim söz konusu değildir. Bununla birlikte muhafazakârların dindar olduğu yanılgısına da düşmemek gerekir. Oakeshott ve Hume gibi dindar olmayan pek çok muhafazakâr bulunmaktadır. Ancak söz konusu isimler buna karşın dinin bir istikrar unsuru olduğunu kabul etmektedirler.

Toplumsal birlikteliği ve istikrarı sağlaması bakımından din, gerek siyasî muhafazakârlık için gerekse durumsal muhafazakârlık için eşit derecede önemlidir. Fakat siyasî muhafazakârlıkta dinin "birey ve devlet arasındaki tampon kurum" olması ile öne çıktığını; durumsal muhafazakârlıkta ise toplumu ayakta tutan ve birleştiren unsur olarak ön plana çıktığını söylememiz mümkündür. İlk haliyle din, devletin gücü ve keyfi yetkisi üzerinde bir otorite kurarak devletin otoritesini sınırlamakta ve bireyi devlete karşı korumaktadır. İkinci haliyle ise din, insanları kanaatkâr yapmak suretiyle disiplinli bir toplum yaratılmasına katkı sağlamakta, bireyin otokontrol sağlamasına yardımcı olmakta ve toplumun birlikteliğini sağlamaktadır (Şeyhanlığlu 2014: 97). Bununla birlikte siyasî muhafazakârlıkta sık sık din ve devletin birbirinin alanını işgal etmemesi gerektiği de vurgulanmıştır. Nasıl ki devrim yoluyla bir topluma müdahale edilemeyeceği savunuluyorsa, aynı şekilde dinin de siyasî bir dönüştürücü araç olarak kullanılmayacağı ifade edilmiştir. Muhafazakâr düşünür T. S. Eliot'un "ulusal bir kilisenin ulusalcı bir hale getirilemeyeceğini" ifade etmesi bu durumu açıklamaktadır (Şeyhanlığlu 2014: 98).

Bu bağlamda din, çalışmamıza konu olan her iki muhafazakârlık için de vazgeçilmez bir unsurdur. Her ideolojinin kendi doğrularını hakikat olarak kabul ettiği ve bu "hakikati" hâkim kılmaya çalıştığı bilinen bir gerçektir. Bu bağlamda muhafazakârlık bir ideoloji olarak ele alındığında bir dinin kabulüne ilişkin toplum üzerinde baskı oluşturacağı düşüncesi akla gelebilir. Ancak siyasî muhafazakârlıkta böyle bir baskı oluşturulması söz konusu değildir. Siyasî muhafazakârlığın hedeflediği şey toplum tarafından benimsenen dinin gerek bireylerin gerekse devletin hiçbir müdahalesiyle karşılaşmamasıdır.

\section{Xitliye}




\subsection{Değişim}

Değişime karşı tutum, muhafazakâr düşüncenin en önemli özelliklerinden biridir. Değişim, muhafazakârların genellikle karşısında direnç gösterdiği bir unsurdur. Öyle ki Oakeshott'a göre muhafazakâr için değişim kimliğe tehdittir ve yok oluşun bir göstergesidir (1991: 170-171). Bu sebeple muhafazakâr biri değişimlere kayıtsız kalamayacaktır. Elbette bu, değişimin tümden reddi anlamına gelmemektedir. Nitekim muhafazakârlığı düzeni yıkmaya yönelik her tür girişime karşı mevcut düzeni savunan düşünce sistemi olarak tanımlayan Huntington, bu durumu değişim karşıtlı̆̆ı olarak değerlendirmemektedir. Aksine siyasî ve toplumsal düzenin sağlanması ve temel unsurlarının korunması için pek çok ikincil konuda değişimin kabullenilmesinin zorunlu olduğunu belirtmiştir (Duman 2017a: 810). Ancak bir değişim olacaksa, muhafazakâr kişi bunun tedricen gerçekleşmesini tercih edecektir. Diğer taraftan muhafazakâr için temel problemin değişim değil, hâkim sınıfların altüst olması ve üst tabaka hayatının sarsılması olduğunu belirten kişiler de mevcuttur (Mert 2002: 73). Diğer bir deyişle muhafazakârlar; toplumsal hiyerarşiler, kurumlar, değerler vb. unsurların sarsılmasını istememekte, bu yüzden de değişime karşı tedbirli bir tavır almaktadırlar.

Russell Kirk de muhafazakârların değişim ve ilerleme karşıtı olduğu düşüncesine katılmamaktadır. Süreklilik ve değişim mefhumlarına vurgu yapan Kirk, süreklilikle topluma istikrar ve devam sağlayan inançları, yani geleneği ifade etmektedir (2005b: 12). Ona göre sürekliliğin olmaması durumunda toplum anarşiye sürüklenecektir. Fakat Kirk, toplumda gelişmenin de gerekli olduğunu belirtmektedir. Gelişme ise halkı reforma teşvik eden anlayış ve çıkarların varlığıdır. Bu gelişmenin olmaması durumunda halk durgunlaşacak ve John Stuart Mill'in dediği gibi uyuşuklaşacaktır. ${ }^{1}$ Dolayısıyla Kirk, muhafazakâr kişinin makul ve 1lımlı ilerlemeyi destekleyeceğini söylemektedir (2005b: 12-13). Tüm bunların yanında Kirk, sürekliliğin gelişimden önce geldiğinin de altını çizmektedir. Çünkü eski ve denenmiş olanı, yeni ve denenmemiş olana tercih etmek her zaman için daha yeğdir. Burke'e göre de bazı değişim araçlarına sahip olamayan bir devlet, onu muhafaza etme araçlarından da yoksun olacaktır (Özipek 2011: 118-119).

Değişim, durumsal muhafazakârlığın en çok öne çıkan temasıdır. Öyle ki durumsal muhafazakârlık çoğu zaman değişime yönelik tutum üzerinden tanımlanmaktadır. Her ideolojinin kendi içinde değişmez ilkeleri vardır ve bu ilkelerin korunması için yoğun bir çaba harcanmaktadır. Bu anlamda siyasî muhafazakârlıktan farklı olarak durumsal muhafazakârlık, diğer ideolojilere eklemlenebilmekte ve bu ideolojilerin mevcut doktrinlerinin koruyucusu

\footnotetext{
1 "Değişime yönelik tutum" muhafazakârlık ve liberallik kıyaslamasında ön plana çıkmış ve iki sistem arasındaki farklılığın belirleyicilerinden biri olmuştur. Zira muhafazakârların aksine liberaller var olan düzenin değişimini arzulamaktadır. Bunun doğal bir sonucu olarak da liberaller, muhafazakârlardan daha aktiftir. Bu sebeple John Stuart Mill, muhafazakârları "uyuşuk kesim" olarak değerlendirmektedir (Kirk 2005b: 12).
} 
olabilmektedir. Zira durumsal muhafazakârlıkta esas olan şey içerikten ziyade biçimdir. $\mathrm{Bu}$ bağlamda sosyalist öğretilerin korunmasına yönelik tutum da muhafazakârlık olarak değerlendirilebilir. Çünkü durumsal muhafazakârlık, esas olarak muhafaza etmeyi ifade etmektedir; neyin muhafaza edildiğini değil. Bu haliyle durumsal muhafazakârlık, ideolojiler üstü bir konuma erişmektedir.

\subsection{Devlet ve Otorite}

Muhafazakârlığın devletin kökenine ve meşruiyetine ilişkin olarak modern dönemde gündeme getirilen ve çeşitli düşünürler tarafından farklı şekillerde ifade edilen "toplum sözleşmesi" anlayışına mesafeli durduğunu söylemek mümkündür (Duman 2017b: 152). Toplum sözleşmesi devleti bir sözleşmeyle temellendirirken sözleşme öncesi bir "doğal hâl"in var olduğunu da göstermektedir. Muhafazakârlara göre ise tarihsel ve toplumsal özelliklerden sıyrılmış bir "soyut insan" veya "doğa durumu" mevcut değildir. Zira insan farklı şekillerde de olsa her zaman için belirli bir toplumsallık içinde yaşamıştır. Dolayısıyla devleti bireysel iradelere ve akılcı ilkelere dayanan kurucu bir sözleşme fikrinden hareket ederek ifade etmek hem topluma hem de devlete ilişkin bir tür yapaylık algısı yaratarak toplumsal ve siyasî düzeni mekanik bir basitlikte çözümlemeye çalışmak anlamına gelmektedir (Duman 2011: 46). Bununla birlikte devlet, bireysel iradenin üzerinde yükselmiş değildir. O süreklilik taşıyan organik toplumsal düzenin en önemli parçalarından biridir.

Fransiz Devrimi ile birlikte modern devlet, birey ve devlet arasında tampon görevi gören aile, kilise, lonca vb. gibi kurumları zayıflatmıştır. Bu durum bireyin devletle aracısız bir șekilde karşı karşıya kalmasına sebep olmuş, birey devletin otoritesini çıplak bir şekilde hissetmiştir. Böylece modern devletle birlikte insanların içinde bağımsız bir şekilde hareket ettiği kurumlar, devlet otoritesinin baskısı altında kalmaya başlamıştır. Muhafazakârlara göre modern dönemde yaşanan toplumsal ve siyasî sorunların çoğunun temelinde devletin gittikçe artan ve totaliter bir şekil alan müdahaleciliği ve tampon kurumların iktidarını gasp etmesi yatmaktadır (Duman 2011: 49-50). Muhafazakârların Fransız Devrimi'ne şiddetle karşı çıkmalarının en temel sebebi de devrimin söz konusu tampon kurumları yıkmaya yönelik olmasıdır. Böylelikle bireyler, devlet karşısında korunması ve savunmasız kalmıştır. Bu sebeple muhafazakâr düşüncede "modern devletin" sınırlanmasına yönelik argümanlarla karşılaşmak mümkündür. İktidar ise ancak bir başka iktidarla sınırlandırılabilecektir. Devletin iktidarını sınırlayacak diğer iktidar ise bahsedilen tampon kurumlardir.

Muhafazakârların siyasî aygıt olarak devlet anlayışına bakıldığında insan hakları, demokrasi, eşitlik vb. gibi ideallere uzak durdukları görülmektedir. Onlar için önemli ve öncelikli olan şey birey, tampon kurumlar ve devlet arasındaki ilişkidir. Devlet bireysel iradelerin belirleyiciliğinden koparılmış, tarihseltoplumsal sürecin doğal bir ürünü olan gelenekler ve teamüllerle ilişkilendirilmiş; çeşitli tampon kurumlarla da iktidarı sınırlandırılmıştır (Duman 2011: 50-53). Bir başka deyişle muhafazakârlara göre insan doğasının ve toplumun kusurlu yapısı

\section{Xillige}


sebebiyle toplumsal hayatta zorunlu olarak farklı düzeylerde otoriteler oluşmuştur. Gerçekten de toplum, muhafazakârların gözünde kırılgan bir şeydir ve anarşik çöküşlerin etkisi altına girmeye müsaittir. Bu bağlamda otorite, anarşiye karşı bir güvencedir. Bununla birlikte siyasî otorite, bireyi ve toplumu yutmamalı, onları kendi alanlarında hareket etmekte serbest bırakmalıdır. Bu durum ise ancak siyasî otoritenin başka bir otorite ile dengelenmesiyle mümkün olacaktır. Muhafazakâr düşüncede otorite; birey, tampon kurumlar ve devletin birbiriyle olan ilişkilerini belirlemede önemli bir role sahiptir. Otoritenin, söz konusu üç unsur arasında paylaşılmaması durumunda tiranlaşma riski mevcuttur. Bu sebeple sivil toplum, cemaatler, loncalar gibi kurum veya kuruluşlar, tiranlaşma riski bulunan otoriteyi ve iktidarı frenleme mekanizması olarak görülmektedir. Bir toplumda sivil örgütlerin zayıf olması durumunda iktidar yozlaşabilecek, bu yozlaşma ise sosyopolitik düzeni yıkabilecektir.

Hem siyasî hem de durumsal muhafazakârlıkta toplumsal sinifların, otorite anlayışının doğal bir sonucu olduğu görülmektedir. Zorunlu ve faydalı olduğuna inanılan otoritenin toplumun doğasında köklendiği düşünülmektedir. Bir başka deyişle otorite, okullarda öğretmen tarafından, iş yerinde işveren tarafından kullanılmaktadır. Bu aynı zamanda insanlara ne yapmaları ve ne yapmamaları gerektiğini söylemekte, sorumlulukların da sınırlarını çizmektedir. Bu anlamda düzenin vazgeçilmez bir parçasını oluşturmaktadır. Aynı zamanda bir itaati kendinde barındıran otorite, hiyerarşiyi de beraberinde getirmekledir. Zira otorite, emir veren ve itaat eden, talep eden ve talebi yerine getiren sınıfları doğurmaktadır. Otoritenin zorunluluğunu savunan muhafazakâr düşünceye göre toplum doğas1 gereği hiyerarşik bir yapıya sahiptir. Bu sebeple sosyal eşitlik, başarılamaz bir ideal olarak görülmektedir. Bu yaklaşım ideoloji olarak ele alınan muhafazakârlığın "aristokrasi ideolojisi" olarak değerlendirilmesine sebep olmuştur.

Siyasi bir ideoloji olarak ele alındığında muhafazakârlığın otorite vurgusu onun kimi zaman otoriter kimi zaman da paternalist olarak değerlendirilmesine sebep olmuştur. Paternalizm, otoritenin zararı engelleme ve fayda sağlama amacıyla diğerleri üzerinde kullanılmasını ifade etmektedir. Joel Feinberg, kendi kendilerine zarar vermelerini engellemek, kendi iyilerini oluşturabilmek için insanlara rehberlik etmek ve "daddy knows best" (baba en iyisini bilir) görüşüyle otoriteye uyum sağlamanın, paternalizmin temel ilkeleri olduğunu ifade etmektedir (Feinberg 1971: 105-125). Muhafazakârlık içinde bu tür çeşitliliklere (otoriteryen, paternalist) rastlamak mümkündür. Ancak otoriter muhafazakârlık kadar otoriteryen siyasete karşı çıkan ve demokrasiyi daha sağlam ve güçlü kılmaya çalışan gelenekler de mevcuttur. Anglo-Amerikan muhafazakâr geleneği bu geleneğin temsilcilerinden kabul edilmektedir.

\subsection{Aile ve Toplum}

Hem siyasî muhafazakârlıkta hem de durumsal muhafazakârlıkta aile ve toplum büyük öneme sahiptir. Muhafazakâr düşüncede toplum, bireylerden oluşan

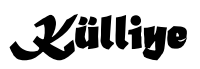


bir bütün olarak değil; organik bir varlık olarak değerlendirilmektedir. Zira bireysel akıl; tarih, tecrübe ve aşkın olanla sınırlandırılmıştır. Bunun bir sonucu olarak da toplumun inşa edicisi olarak değil, parçası olarak kabul edilmektedir. Birey, toplumu var etmemekle birlikte toplum içinde var olmaktadır. İnsanlar güvenlik arayışında olan bağımlı varlıklardır. Toplum bu ihtiyaçları karşılamaktadır. Toplumdan koparılamayan birey, onu besleyen sosyal grupların(aile, arkadaşlar, meslektaşlar, vb.) bir parçası olmak durumundadır.

Maistre, Lammenais, Müller gibi düşünürler, insan bedeni ile toplum arasında bir benzeşim kurmuştur. Buna göre insanın organları arasında bir iş bölümü vardır ve bu işleyiş toplumda da mevcuttur. Toplumun içindeki parçalar arasındaki ilişki çatışmacı bir ilişki değildir. Burada uzlaşmacı, uyumlu bir bağlılık ve ilişki söz konusudur. Toplum, içinde sınıfları ve bazı sosyal grupları barındırmaktadır. Bu sınıflar veya sosyal gruplardan bir olmaksızın diğeri işlevini yerine getiremeyecektir. Muhafazakâr öğretiye göre insanın içinde bulunduğu dünya ve düzen, mümkün olanların en iyisidir. Bu sebeple toplumsal yapıdaki eşitsizlikler, sınıflar ve çeşitlilikler bu düzenin bir parçası olarak görülmekte ve bunları yok etmeye veya değiştirmeye yönelik herhangi bir eylemde bulunulmamaktadır. Toplum anlayışı hiyerarşi, otorite, devlet anlayışıyla iç içe geçmiş vaziyettedir. Söz konusu ilişki ağında devlet ikincil konuma alınırken toplumsal kurumlar ön plana çıkarılmıştır. Burke'ün sivil toplum kuruluşlarını ve gönüllü kuruluşları 'küçük müfrezeler" olarak tanımlaması bu bağlamda anlamlıdır (Özipek 2011: 99).

Aile ise toplumun temel unsuru olarak görülmektedir. Sağlıklı bir aile, toplumun istikrarı için gereklidir. Bu sebeple aile korunmalı ve gerek duyulursa güçlendirilmelidir. Aile de organik bir yapı olmakla birlikte aşk, sorumluluk, paylaşım gibi doğal dürtülerin bir ürünü olarak değerlendirilmektedir. Aynı zamanda toplumsal değerlerin aktarımı, nesillerin devamı, sosyalleşme gibi toplumun önemli işlevlerini yerine getirmesi bakımından da önem taşımaktadır. Aile, aynı çatı altında yaşamak demek değildir; karşılıklı kan bağıyla kurulan, inançla gelişen, sevgi ile güçlenen ideal bir kurumdur. Bu sebeple muhafazakârlar pornografi, kürtaj, ötenazi vb. gibi durumlara karşı çıkmakta; evliliğin teşvik edilmesi ve ailenin korunmasını talep etmektedir (Vural 2011: 64).

\subsection{Mülkiyet}

Mülkiyet, muhafazakâr düşünürlerin üzerinde uzlaştığı konuların başında gelmektedir. Hemen hepsine göre mülkiyet edinme ve onu koruma hakk1, iyi bir toplum tanımının ilk şartıdır. Mülkiyet toplumsal hayatta insana bir statü tesis etmekte ve toplumun bazı üyelerinin kendilerini geliştirerek toplumu yönetecek seviyeye gelmesine olanak sağlamaktadır. Burke'ün düşüncesinde mülkiyetin korunmas1, sivil toplum hedeflerinin arasında yer almaktadır. 1772'de parlamentoda yaptığı bir konuşmada Burke, "İnsanlardan, toplumun onların korunması için kurulduğu yaşamlarını, özgürlüklerini veya mülklerini almak büyük 
zorluk ve müsamaha gösterilemez bir tiranlıktır" diyerek, mülkiyeti toplumun hedefi olarak belirlemiştir (Canavan 2011: 12).

Nisbet, muhafazakâr mülkiyet teorisinde güçlü bir Roma karakteristiği olduğunu belirtmektedir. Buna göre mülkiyet, insan ihtiyacının cansız hizmetçisidir ve her şeyin üzerinde insaniyetin bütün doğa üzerindeki üstünlüğünün koşuludur (Nisbet 2011: 80). Muhafazakârların mülkiyete bakış açısı, yardıma muhtaç olanlara ve fakirlere karşı kayıtsız kaldıkları anlamına gelmemelidir. Onlara göre aile, mahalle, kilise vb. şeyleri de içine alan gruplar, aynı zamanda yardımlaşma için vardır. Buradaki yardım bürokratik bir yardım değildir. Zira Burke'e göre yardım devletin değil, tampon kurumların görevidir (Nisbet 2011: 82). Nitekim bu kurumlar bireye devletten çok daha yakındır onu daha iyi anlamaktadır. Fakat söz konusu yardımlar sınıfları bertaraf etmeye yönelik değildir.

Mülkiyet aynı zamanda insanlarda mülk edinme ve bunun için çalışma hırsını beraberinde getirmektedir. Mülk sahibi olduğu oranda da başkalarına bağımlılığı azalmakta ve daha özgür bir hale gelmektedir. Toplumsal eşitlik gibi ekonomik eşitlik de muhafazakârlar için gerçekçi ve kabul edilebilir bir söylem değildir. Özel mülkiyet, aynı zamanda devlete karşı bireyin kendi bağımsızlığını ve güvenliğini sağlama alması da ifade etmektedir. Muhafazakârlar için meşruiyetin tek kaynağı devlet değildir. Toplum hayatında geleneklerin, içtihat hukukunun ve yerleşmiş olan mülkiyet haklarının önemli bir değeri vardır (Aktan 2007: 53).

Gerek siyasî muhafazakârlıkta gerekse durumsal muhafazakârlıkta mülkiyet hakkı, özgürlükle birlikte değerlendirilmektedir. Özel mülkiyetin korunması özgürlüklerin güvence altına alınması olarak yorumlanmaktadır. Diğer taraftan siyasî muhafazakârlık için mülkiyet hakkının varlığı, devletleşme yerine sivilleşmenin artırılması anlamını taşımaktadır. $\mathrm{Bu}$ bağlamda siyasî muhafazakârlık, kamulaştırmanın karşısında yer almaktadır. Devletin müdahalesi ise ancak mülkiyetin bireyler tarafından diğerleri üzerinde bir baskı aracı olarak kullanılması durumunda meşru görülmektedir. Bir ideoloji olarak değerlendirildiğinde muhafazakârlığın mülkiyete yönelik yaklaşımı, diğer önemli ideolojilerden biri olan klasik liberalizm ile ortaklık göstermektedir. Fakat klasik liberallerin aksine, mülkiyet hakkı bireyci mülkiyet hakkı teorisine dayanmamaktadır; özel mülkiyetin önemi sosyal dengeye yaptığı katkıya dayanmaktadır (Aktan 2007: 53). Bu durumu muhafazakârların "mülkiyet hak değil sorumluluktur" ilkesi net bir şekilde açıklamaktadır. Bu ilkeye göre mülkiyet hakkı, kişinin kendine ait olanla dilediğini yapabileceği bir hak değildir; bilakis toplumun ihtiyaçlarıyla sınırlıdır (Aktan 2007: 53).

\subsection{Ahlaki Düzen}

Hem siyasî hem de durumsal muhafazakârlıkta ahlak vurgusu büyük bir önem taşımaktadır. Muhafazakârlıkta ahlaka atfedilen önem o kadar büyüktür ki muhafazakârlığı ahlak ve ahlaki olanın geri çağrılışı olarak betimleyenler dahi olmuştur (Genç-Coşkun 2015: 34). Dolayısıyla muhafazakâr olmanın aynı zamanda

\section{Xillige}


ahlaki bir konumlanışı da beraberinde getirdiğini söylememiz mümkündür. Söz konusu ahlaki konumlanış ise kendini tarihsel süreç içinde toplumsal varoluş formlarında açığa çıkarmaktadır.

Aydınlanma ile birlikte insan merkezi konuma getirilmiş ve düzenin yaratıcısı olarak tasarlanmıştır. Burke, Aydınlanma'nın rasyonalist ahlak anlayışına şiddetle karşı çıkmış ve insan aklının yetersizliğine, insanın kusurlu bir varlık olduğuna dikkat çekmiştir. Ona göre mevcut düzen, insan aklının ve becerisinin çok üstündedir. Bu sebeple insan, hiçbir zaman tam olarak çözemeyeceği esrarlı geçek karşısında mütevazı olmak durumundadır (Burke 1977: 63'ten aktaran; Duman 2009: 17-18). Dolayısıyla Burke'e göre rasyonalist bir ahlak anlayışı söz konusu değildir; bu doğrultuda akıl ahlaki ilkelere müdahalede bulunmamalıdır. Başka bir deyişle ahlaki normlar, bilinçli bir yapımı değil doğal bir oluşumu ifade etmektedir. Söz konusu "doğal anayasalar" muhafazakârlı çeşitlerinde farklı temellendirilmekle birlikte ortak bir vurguyu oluşturmaktadır. Maistre, doğal anayasanın yazılı yasalardan üstün olduğunu belirtmiştir. Ona göre her anayasa bir yaratıştır ve her yaratış insan kudretinin ötesindedir (Özipek 2011: 103-104).

\section{Sonuç}

Muhafazakârlık, geleneksel ve sosyal etmenlerin muhafaza edilmesini savunan politik bir bakış açısını ve bireysel bir tavır alışı ifade etmektedir. Üzerinde uzlaşılmış bir tanımı olamamakla birlikte muhafazakârlık, iki temel yaklaşım üzerinden ele alınmaktadır. Bunların ilki muhafazakârlığı bir siyasî ideoloji olarak değerlendirirken, ikincisi davranışlar dizisi, tavır ve tutum olarak kabul etmektedir. Birinci yaklaşımda muhafazakârlık, Fransız Devrimi'nden sonra teşekkül eden ve devrimin getirmiş olduğu modern ilkelere karşı çıkan bir ideoloji olarak kabul edilmektedir. İkinci yaklaşımda ise muhafazakârlık, katı doktriner içeriğe sahip olmayan davranış veya dünyayı algılama biçimini ifade etmektedir.

Her iki yaklaşımın da kendi içerisinde bazı çıkmazları mevcuttur. Zira her ne kadar tanımı üzerinde görüş birliği bulunmasa da ideolojinin özellikleri arasında insanlara sunulan bir ütopyanın varlığı, üzerinde anlaşılmış bir konudur. Fakat muhafazakârlığın insanlara sunduğu bir ütopyası yoktur. Nitekim bazı düşünürler, bir ütopyası olmadığı için muhafazakârlığın ideoloji olarak kabul edilemeyeceğini belirtmiştir. Ayrıca muhafazakârlık; liberalizm, sosyalizm veya faşizm gibi ideolojilerde var olan keskin çizgelere sahip değildir. Her ülkede veya toplumda farklı muhafazakârlık varyasyonlarına rastlamak mümkündür. $\mathrm{Bu}$ durum muhafazakârlığın ideoloji olarak ele alınmasını güçleştirmektedir. Diğer taraftan muhafazakârlığ 1 bir tutum veya davranış olarak ele almak onu her toplumda var olan ve tam olarak ne zaman ortaya çıktığı belirlenemeyen bir unsur haline getirecektir. Bununla birlikte tutum ve davranışlar, içerisinde pek çok gündelik eylemi de barındırmaktadır. Böylece hangi davranışların muhafazakâr olup hangilerinin olmadığı bir sorun oluşturacak; bu da muhafazakârlığın tespitini daha zor hale getirecektir. Bu bağlamda muhafazakârlığın ana temaları, muhafazakârlığı

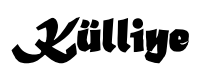


anlama noktasında kilit bir rol oynamaktadır. Gelenek, değişim, din, devlet, otorite, aile, toplum, mülkiyet ve ahlaki düzen muhafazakârlığın en önemli temalarını oluşturmaktadır. Siyasî ve durumsal muhafazakârlığın bu temalara yaklaşımı büyük ölçüde örtüşse de arada bazı küçük farklılıklar bulunmaktadır.

Gelenek, her şeyden önce toplumun kimliğini ifade etmektedir. Bu bağlamda hem siyasî hem durumsal muhafazakârlık için gelenek hayati bir öneme sahiptir. Ancak siyasî muhafazakârlıkta gelenek, daha ziyade sosyal veya siyasi kurumları temsil etmektedir. Durumsal muhafazakârlıkta ise gelenek, daha çok toplumsal norm ve değerler olarak ön plana çıkmaktadır.

Değişime karşı ihtiyatlı tutum, muhafazakârlığın temel karakteridir. Fakat özellikle durumsal muhafazakârlık, değişime yönelik tutum üzerinden açıklanmaktadır. Bu doğrultuda her ideolojinin kesin ilkeleri olduğu ve bu ilkelerin korunmaya çalışıldığı düşünüldüğünde durumsal muhafazakârlık diğer ideolojilere eklemlenebilmektedir. Başka bir deyişle siyasî muhafazakârlık bir ideolojiyi ifade ederken durumsal muhafazakârlık herhangi bir ideolojinin korunmasını ifade etmektedir. Bu haliyle durumsal muhafazakârlık söz konusu olduğunda sosyalist bir şahıs da kapitalist bir şahıs da muhafazakâr olarak adlandırılabilecektir.

Muhafazakârlıkta devlet, otorite ve hiyerarşi kavramları birbiriyle ilintili şekilde ele alınmaktadır. Muhafazakâr düşüncede otorite; birey, tampon kurumlar ve devletin birbiriyle olan ilişkilerini belirlemede önemli bir role sahiptir. Hem siyasî hem de durumsal muhafazakârlıkta toplumsal sınıflar, otoritenin sonucu olarak görülmektedir. Otoritenin zorunluluğunu savunan muhafazakâr düşünceye göre toplum doğası gereği hiyerarşik bir yapıya sahiptir. Bu sebeple sosyal eşitlik, başarılamaz bir ideal olarak görülmektedir. Bu yaklaşım, siyasî muhafazakârlığın "aristokrasi ideolojisi”" olarak değerlendirilmesine sebep olmuştur. Diğer taraftan otorite vurgusu, siyasî muhafazakârlığın otoriter veya paternalist olarak değerlendirilmesine yol açmıştır.

Gerek siyasî muhafazakârlıkta gerekse durumsal muhafazakârlıkta mülkiyet hakk1, özgürlükle birlikte değerlendirilmektedir. Özel mülkiyetin korunması özgürlüklerin güvence altına alınması olarak yorumlanmaktadır. Diğer taraftan siyasî muhafazakârlık için mülkiyet hakkının varlığı, devletleşme yerine sivilleşmenin artırılması anlamını taşımaktadır. $\mathrm{Bu}$ bağlamda siyasî muhafazakârlık, kamulaştırmanın karşısında yer almaktadır.

Aile, toplum ve ahlaki düzen hem durumsal hem siyasî muhafazakârlıkta eşit derece öneme sahiptir. Her iki yaklaşım için de aile, toplumun yap1 taş1 değerlendirilmekte; toplum ise bireylerden oluşan bir bütün olarak değil organik bir varlık olarak görülmektedir. Her iki yaklaşımda da birey, toplum içinde var olmaktadır. Son olarak gerek siyasî gerek durumsal muhafazakârlıkta Tanrı, evren, doğa, siyaset gibi alanların hepsi ahlaki bir düzen üzerine inşa edilmiş ve ahlaki bir konumlanışı gerektirmiştir. 
Genel olarak bakıldığında ise durumsal muhafazakârlığın daha bireysel bir tavır alışı; siyasî muhafazakârlığın ise daha kurumsallaşmış bir düşünce sistemini ifade ettiğini söylememiz mümkündür. Diğer taraftan durumsal muhafazakârlık, esasında her toplumda var olan korumacı bir dürtüyü ifade etmektedir. Bu anlamda Fransız Devrimi ile ortaya çıkan siyasî muhafazakârlıktan çok daha eskiye dayandığı açıktır. Bu durumda siyasî muhafazakârlığı, zaten her toplumda farklı şekillerde mevcut olan muhafazakâr tutumun Fransız Devrimi ile birlikte, devrime karşı, örgütlü bir hal alması şeklinde değerlendirmek mümkündür. Böylece durumsal muhafazakârlık, siyasî muhafazakârlığın temel ve kavramsal çerçevesini oluşturan unsur halini alacaktır.

\section{Kaynakça}

Akıncı, Mehmet (2009). "Değişime Direniş mi Yoksa İhtiyatlı Değişimi Savunmak mi?" Aksaray Üniversitesi İIBF Dergisi, 1 (1): 133-148.

Bakan, Selahaddin-Arpacı, Işıl (2013). "Liberal Değişim Sürecinde Dönüşen ve Dönüştüren Muhafazakârlık". Kahramanmaraş Sütçü İmam Üniversitesi İIBF Dergisi. 2(2): 131-141.

Beneton, Philippe (1991). Muhafazakârlık. Çev. Cüneyt Akalın. İstanbul: İletişim Yayınları.

Canavan, Francis (2011). "Edmund Burke'de Mülkiyet ve Hükümet". Çev. Celaleddin Güngör. Muhafazakâr Düşünce Dergisi. 7(27): 11-38.

Duman, Fatih (2009). "Evrensellik ve Tarihsellik Arasında Edmund Burke: Ahlakın/Siyasetin Felsefi Temelleri”. Muhafazakâr Düşünce Dergisi. 5(19-20): 9-34.

Duman, Fatih (2011). "Muhafazakâr Düşüncede Devlet Kavramı Üzerine Eleștirel Bir Değerlendirme”. Muhafazakâr Düşünce Dergisi. 7(28): 33-63.

Duman, Fatih (2017a). "Durumsal Muhafazakârlık Anlayışı Üzerine Teorik ve Eleştirel Bir Değerlendirme". Hitit Üniversitesi Sosyal Bilimler Enstitüsü Dergisi. 10(2): 797-818.

Duman, Fatih (2017b). "Muhafazakâr Düşüncede 'Otorite' Anlayışı". Milel ve Nihal Dergisi. 14(1): 135-159.

Erdoğan, Mustafa (2004). "Muhafazakârlıkta Ana Temalar”. Liberal Düşünce. 34: $5-9$.

Ergil, Doğu (1986). İdeoloji. Ankara: S Yayınları.

Feinberg, J. (1971). "Legal Paternalism". Canadian Journal Of Philosophy, 1(1): 105-125. 
Genç, Ernur-Coşkun, Tuba (2015). "Muhafazakârlık ve Türkiye Muhafazakârlıklarının Bazı Halleri”. Niğde Üniversitesi İIBF Dergisi. 8(1): 2740 .

Harrries, Owen (2003). "What It Mean To Be Conservative". Policy Magazine. 19(2): 28-38.

Heywood, Andrew (2013). Siyasi İdeolojiler. Çev. Ahmet Kemal Bayram, Özgür Tüfekçi, Hüsamettin İnaç, Şeyma Akın, Buğra Kalkan. Ankara: Adres Yayınları.

Huntington, Samuel P (1957). "Conservatism as an Ideology". The American Political Science Review, 51(2): 454-473.

Kirk, Russel (2005a). "Muhafazakârlık Fikri”. Çev. Bengül Güngörmez. Liberal Düşünce, 10(37): 137-143.

Kirk, Russel (2005b). "Süreklilik ve Değişim”. Çev. Faruk Çakır. Muhafazakâr Düşünce Dergisi, 1(4): 11-26.

Mannheim, Karl (2004). İdeoloji ve Ütopya. Çev. M. Okyavuz. Ankara: Epos Yayınları.

Meriç, Cemil (2015). Bu Ülke. Ankara: İletişim Yayınları.

Mert, Nuray (2002). "Muhafazakârlar Neyi Muhafaza Etmeye Çalışır?”. Tezkire, 11(27-28): 72-77.

Mollaer, Fırat (2009). Muhafazakârlı̆̆ın İki Yüzü. İstanbul: Dergah.

Nisbet, Robert (2011). "Mülkiyet ve Hayat". Çev. Fatih Serenli ve Kudret Bülbül. Muhafazakâr Düşünce Dergisi. 7(27): 80-93.

Oakeshott, Michael J (1991). "On Being Conservative". Rationalism in Politics and Other Essays. ed. Timothy Fuller. London: Liberty Press.

Özipek, Bekir Berat (2011). Muhafazakârlık: Akıl, Toplum, Siyaset. İstanbul: Timaş Yayınları.

Şeyhanlığlu, Hüseyin (2014). "Siyasî Muhafazakârlığın Temel İlkeleri”. Muhafazakâr Düşünce Dergisi. 10(40): 80-107.

Vural, Mehmet (2011). Siyaset Felsefesi Açısından Muhafazakârlık. Ankara: Elis Yayınları.

Y1lmaz Ceylan, Ayşe (2007). "Edmund Burke'ün Muhafazakâr Düşüncesinde İyi Devrim Kötü Devrim Ayrımı”. Muhafazakâr Düşünce. 3 (11): 23-43. 